\title{
Pembebasan Jerat Feminisasi Kemiskinan
}

\author{
Fawziah Zahrawati B \\ Fakultas Tarbiyah, IAIN Parepare, Parepare, 91131, Indonesia \\ *email: zahraburhan42@gmail.com
}

\begin{abstract}
Abstrak
Fenomena feminisasi kemiskinan bukan merupakan isu baru dalam konteks kemiskinan. Indonesia dalam sejarah dan proses belum pernah bebas dari persoalan tersebut. Feminisasi kemiskinan merupakan hilangnya peluang-peluang dan kebebasan perempuan dalam menentukan pilihan hidup, sehingga menjadikan mereka tidak memperoleh fasilitas-fasilitas pendidikan, ekonomi dasar, pekerjaan, perlindungan keamanan, dan keterlibatan politik. Banyak para pengamat ekonomi pada awalnya melihat masalah ini sebagai sesuatu yang selalu berkaitan dengan faktor-faktor ekonomi saja. Padahal, hal tersebut terjadi sebagai akibat dari kemiskinan kultural dan kemiskinan struktural yang pada akhirnya membatasi perempuan untuk mengakses fasilitas-fasilitas dan sumber daya yang ada. Sekalipun sudah dilahirkan berbagai landasan hukum untuk meningkatkan kesetaraan gender agar dapat menanggulangi feminisasi kemiskinan, namun masih saja persoalan tersebut belum dapat teratasi, dikarenakan nilai-nilai dan mentalitas masyarakat yang masih bias gender. Oleh karena itu, upaya yang harus ditempuh untuk membebaskan jerat feminisasi kemiskinan yaitu mengubah nilainilai yang ada di masyarakat dan mengubah struktur menjadi lebih terbuka kepada kaum perempuan dengan menyediakan pendidikan dan pekerjaan yang nondiskriminatif.
\end{abstract}

Kata Kunci: kemiskinan, feminisasi kemiskinan, pembebasan

\section{Abstact}

The phenomenon of feminization of poverty is not a new issue in the context of poverty. Indonesia in history and process has never been free from these problems. Feminization of poverty is the loss of opportunities and freedom of women in determining life choices, thus rendering them unable to obtain educational facilities, basic economics, employment, security protection, and political involvement. Many economic observers at first saw this problem as something always related to economic factors alone. In fact, this happens as a result of cultural poverty and structural poverty which ultimately limits women from accessing existing facilities and resources. Even though various legal foundations have been born to improve gender equality in order to overcome the feminization of poverty, the problem has not yet been solved, due to the community's values and mentality that are still gender biased. Therefore, the effort that must be taken to free the snares of feminization of poverty is to change the values in society and change the structure to be more open to women by providing non-discriminatory education and employment.

Keywords: poverty, feminization of poverty, liberation

\section{Pendahuluan}

Kemiskinan merupakan masalah yang serius dan sampai saat ini belum bisa dituntaskan, tidak mengherankan jika hal tersebut mengundang perhatian dunia. Sebagaimana Sustainable 
Development Goals menjadikan kemiskinan sebagai target pertama. Sustainable Development Goals menargetkan pada tahun 2030 extreme poverty sudah tidak ada lagi dan salah satu kalangan yang menjadi target yaitu perempuan. Sebab, perempuan adalah calon ibu yang akan mempunyai peran mendidik, mengasuh atau merawat, dan memberikan kasih sayang, sehingga seorang ibu akan berpengaruh besar terhadap kelangsungan hidup (termasuk kesehatan) anak-anaknya. Selain itu, perempuan lebih banyak yang mengalami kemiskinan. Sebagaimana para feminis menyatakan bahwa seringkali kemiskinan berwajah perempuan, karena perempuan paling menderita dalam situasi miskin yang sama bila dibandingkan dengan laki-laki (Santi, 2007).

Kemiskinan merupakan kata yang tidak pernah berhenti diperdebatkan kalangan intelektual, akademisi, praktisi Lembaga Swadaya Masyarakat (LSM), birokrat, dan mahsiswa disebabkan oleh dampak luar biasa yang dihadirkan oleh kemiskinan tersebut. Kemiskinan menyebabkan hilangnya: (a) kesejahteraan bagi kalangan miskin (sandang, pangan, dan papan), (b) hak akan pendidikan, (c) hak atas kesehatan, (d) tersingkirnya dari pekerjaan layak secara kemanusiaan, (e) termarjinalkan dari hak atas perlindungan hukum, (f) hak atas rasa aman, (g) hak atas partisipasi terhadap pemerintah dan keputusan publik, (h) hak atas spiritualitas, (i) hak untuk berinovasi, dan yang lebih penting (j) hak atas kebebasan hidup (Mutaqien, 2006).

Melihat fenomena feminisasi kemiskinan, sangat berbanding terbalik dengan amanah Undang-Undang Dasar 1945 pasal 27, ayat (1), bahwa: "Segala warga negara bersamaan kedudukannya di dalam hukum dan pemerintahan dan wajib menjunjung tinggi hukum dan pemerintahan itu dengan tidak ada kecualinya." Dan ayat (2) "Tiap-tiap warga negara berhak atas pekerjaan dan penghidupan yang layak bagi kemanusiaan." Hal ini mengisyaratkan agar segala warga masyarakat, tak terkecuali perempuan berhak untuk mengakses fasilitas-fasilitas dan sumber daya yang ada.

Berbagai landasan hukum telah dibuat untuk memberi kesempatan bagi perempuan dalam mengakses fasilitas-fasilitas dan sumber daya yang ada. Namun, masalah feminisasi kemiskinan belum dapat terselesaikan juga. Oleh karena itu, artikel ini berpretensi untuk mengetahui penyebab feminisasi kemiskinan dan bagaimana upaya pembebasan feminisasi kemiskinan demi mewujudkan masyarakat yang sejahtera.

\section{Pembahasan}

\section{Feminisasi Kemiskinan dalam Konsep}

Berbagai ahli mendefinisikan konsep kemiskinan selalu dikaitkan dengan ekonomi atau pendapatan seseorang. Sebut saja, Haughton \& Khandker (2012) menyatakan bahwa masyarakat miskin adalah masyarakat yang penghasilannya termasuk pada kategori di bawah garis kemiskinan. Tidak jauh berbeda, Santrock (2003) mendefenisikan kemiskinan sebagai keadaan perekonomian seseorang yang sulit dengan ambang kemiskinan nasional sebagai alat ukurnya.

Agak sedikit berbeda, definisi kemiskinan yang dikemukakan oleh Listiyaningsih (2004) menyatakan bahwa kemiskinan merupakan seseorang yang mengalami keadaan yang sulit memenuhi kebutuhan dasar berupa kebutuhan pokok seperti sandang, pangan, dan papan, serta kebutuhan pokok yang lainnya. Kemiskinan selama ini hanya dilihat dari dimensi pendapatan saja. Sesungguhnya, tidak dapat dipungkiri bahwa pendapatan merupakan aspek penting dari kemiskinan, namun pendapatan hanya mampu menggambarkan sebagian dari kehidupan manusia yang multidimensional (Listiyaningsih, 2004). Karena, kemiskinan sebenarnya bukan masalah ekonomi semata, melainkan mengandung berbagai isian. Pertama, masalah kemiskinan adalah masalah kerentanan (vulnerability). Kedua adalah masalah tertutupnya akses ke berbagai sumber daya produktif, termasuk modal, sumber daya alam, 
bahkan kesempatan kerja. Ketiga, kemiskinan adalah masalah ketidakpercayaan, perasaan impotensi emosional dan sosial dalam menghadapi kekuasaan dalam hal-hal yang menyangkut pembuatan keputusan yang berhubungan dengan dirinya. Keempat, kemiskinan juga berarti rendahnya ketahanan fisik dan intelektual karena keterbatasan kandungan konsumsi fisik dan non-fisik. Kelima, kemiskinan berbentuk ketergantungan, baik secara fisik, sosial, maupun ekonomi pada pihak lain. Keenam kemiskinan berarti adanya sebuah sistem nilai "kemiskinan" yang diwariskan dari satu generasi ke genersi kemudian disebut sebagai kemiskinan kultural (Sumodiningrat \& Nugroho, 2005).

Kemiskinan merupakan tidak adanya peluang-peluang dan kebebasan untuk menentukan pilihan-pilhan hidup, sehingga memungkinkan manusia mendapatkan fasilitasfasilitas ekonomi dasar, pekerjaan, perlindungan keamanan dan pengakuan identitas kulturalnya (Trijono, 2007). Jika dikaitkan dengan feminisasi kemiskinan, dalam hal ini Henslin (2006) menyatakan bahwa hal tersebut merupakan hubungan antara kemiskinan dan perempuan. Dengan demikian dapat disimpulkan bahwa feminisasi kemiskinan merupakan hilangnya peluang-peluang dan kebebasan perempuan dalam menentukan pilihan hidup, sehingga menjadikan mereka tidak memperoleh fasilitas-fasilitas pendidikan, ekonomi dasar, pekerjaan, perlindungan keamanan, keterlibatan politik, dsb.

\section{Penyebab Feminisasi Kemiskinan}

Feminisasi kemiskinan tidak hanya terjadi di Indonesia. Namun, feminisasi kemiskinan juga terjadi di negara-negara lain, tak terkecuali Amerika Serikat. Sebagaimana yang dinyatakan oleh Schaefer (2012) bahwa di Amerika Serikat, sekitar setengah dari semua perempuan berada dalam garis kemiskinan. Selanjutnya, Schaefer mengemukakan penyebab hal tersebut, yaitu: kepergian, kecacatan, atau kematian suami yang mengakibatkan seorang wanita menjadi kepala rumah tangga yang tunggal. Dari sinilah feminisasi kemiskinan itu terjadi. Di sisi lain, Haughton \& Khandker (2012) menyatakan bahwa penyebab-penyebab utama, atau paling tidak berhubungan dengan kemiskinan antara lain adalah: karakteristik wilayah, masyarakat, rumah tangga, dan individu.

Sementara Listyaningsih (2004) menyatakan bahwa yang menjadi faktor-faktor penyebab seseorang menjadi miskin, yakni: (1) ketidakberuntungan (disadvantages) yang melekat pada keluarga miskin, (2) keterbatasan pemilikan asset (poor), (3) kelemahan kondisi fisik (physically weak), (4) keterisolasian (isolation), (5) kerentanan (vurnerable), dan (6) ketidakberdayaan (powerless). Faktor-faktor tersebut menyebabkan seseorang selalu kekurangan dalam memenuhi kebutuhan pangan, sandang, papan, hidup sehat, serta pendidikan.

Kemudian Mutaqien (2006) menyatakan bahwa faktor yang dinilai sebagai sebab-sebab kemiskinan antara lain: (1) kesempatan kerja, di mana seseorang itu miskin karena menganggur, sehingga tidak memperoleh penghasilan atau kalau bekerja tidak penuh, baik dalam ukuran hari, minggu, bulan, maupun tahun, (2) upah gaji di bawah minimum, (3) produktivitas kerja yang rendah, (4) ketiadaan asset, (5) diskriminasi, (6) tekanan harga, dan (7) penjualan tanah.

Sedangkan Susanto (2006) menyatakan, seseorang atau sekelompok masyarakat itu menjadi miskin karena berbagai faktor penyebab yang bisa dilihat dari dimensi karena keterbatasan akses, pendapatan maupun pengeluaran yang subsisten, kondisi yang rentan terhadap berbagai penyakit, sering terlibat di dalam utang piutang maupun harus menjual barang yang dimiliki untuk kebutuhan subsistennya. Sementara itu, dimensi lainnya, bisa diperlihatkan melalui berbagai kebijakan pemerintah juga bisa berpengaruh terhadap proses redistribusi pendapatan yang tidak seimbang antara berbagai kelompok. Dari berbagai pernyataan tersebut, pada konteks feminisasi kemiskinan disebabkan oleh dua hal, yakni kemiskinan kultural dan kemiskinan struktural. 
Kemiskinan kultural merupakan kemiskinan yang mengacu pada sikap seseorang atau masyarakat yang karena budayanya tidak berusaha untuk memperbaiki tingkat kehidupannya, meskipun ada usaha dari pihak luar untuk membantunya, karena mereka merasa sudah cukup dan merasa tidak kekurangan (Siahaan, 2004). Kemiskinan kultural merupakan budaya malas, tidak produktif, mudah menyerah, percaya total pada nasib dan takdir, malas berusaha, dan malas untuk belajar (Sumodiningrat \& Nugroho, 2005).

Kondisi kemiskinan begitu mendalam dan kronis sifatnya, sehingga mereka menerimanya dengan pasrah, sudah nasib, sudah suratan takdir, yang dalam bahasa ilmiah disebut rintangan-rintangan mental. Gejala selanjutnya menunjukkan bahwa kemiskinan sudah membudaya dalam diri mereka, karena mereka sudah menerimanya dan tidak memperlihatkan keinginan untuk keluar dari kondisi kemelaratan. Mereka sudah terkurung di dalam kebudayaannya sendiri yang disebut sebagai the culture of poverty atau kultur kemelaratan (Kasim, 2006).

Berhubungan dengan hal tersebut, Henslin (2006) menyatakan bahwa "beberapa orang berpandangan bahwa orang miskin cenderung terjebak dalam suatu kebudayaan kemiskinan (culture of poverty)." Tidak jauh berbeda, Oscar Lewis sebagaimana yang dikutip oleh Susanto (2006) mengajukan dua hal yang dianggap sebagai penyebab terjadinya kemiskinan, yaitu: (a) mereka tidak mampu memanfaatkan potensi diri, menyia-nyiakan sumber daya yang ada, dan menjauhkan diri dari kegiatan organisasi kemasyarakatan. Mereka mengecilkan kapasitas pribadi akibatnya mereka menjadi miskin; dan (b) budaya kemiskinan yaitu suatu cara hidup yang diwariskan dari generasi ke generasi melalui garis keturunan keluarga.

Dari pernyataan-pernyataan tersebut, maka jelas bahwa kemiskinan kultural menjadi salah satu penyebab kemiskinan. Berkaitan dengan pengaruh kemiskinan kultural terhadap feminisasi kemiskinan, International Labour Office (2004) menyatakan bahwa kaum wanita miskin lebih menderita karena pada sebagian besar masyarakat, wanita juga menjadi subyek dari nilai-nilai sosial yang membatasi mereka dalam meningkatkan kondisi ekonomi atau menikmati akses yang sama ke pelayanan umum. Di Indonesia, nilai-nilai yang diberlakukan dalam masyarakat dapat berupa pernikahan di usia muda, keharusan segera memiliki anak, kehamilan berkali-kali untuk memperoleh anak laki-laki, dan jam kerja yang panjang di rumah.

Selain itu, pembatasan perempuan untuk menguasai dan mengontrol hak milik melalui legitimasi kekerabatan dan adat, bahkan di perkotaan, telah menyebabkan terjadinya stratifikasi sosial ekonomi menurut gender yang semakin tajam. Padahal, tanpa adanya pembatasan itupun telah terjadi stratifikasi sosial ekonomi menurut gender, karena laki-laki lebih memiliki peluang untuk menjalankan perannya pada posisi-posisi ketenagakerjaan pemerintah maupun swasta dan berbagai bidang profesi, sementara perempuan tetap terikat pada peran utamanya di sektor domestik (Irianto, 2003).

Hal tersebut membuat ketidakmerdekaan perempuan sebagai manusia dalam menentukan hak, kewajiban, dan tanggung jawabanya sendiri. Sampai saat ini, masih banyak hak asasi perempuan sebagai manusia pribadi, dirampas tanpa disadari oleh perempuan itu sendiri. Akibatnya, ketidakadilan terhadap perempuan muncul di mana-mana. Hampir seluruh penderitaan di dunia ini, korban mayoritas adalah perempuan. Situasi tersebut muncul dengan adanya struktur budaya yang dibuat oleh manusia. Menurut (Murniati, 2004), data ini dapat ditelusuri melalui: (a) struktur budaya patriarki yang muncul karena perubahan sosial ke arah masyarakat industri (adanya hak milik atau akumulasi kapital); (b) struktur ekonomi yang menghasilkan suatu sistem yang merugikan perempuan (urusan pangan dibebankan perempuan, perempuan masuk kategori tenaga kerja kurang produktif, kesempatan memimpin bagi perempuan banyak hambatannya); (c) struktur sosial yang memunculkan hubungan hierarkis dalam keluarga, sehingga perempuan menjadi manusia nomor dua. Hubungan hierarkis ini berkembang menjadi hubungan dalam kasta atau lapisan dalam masyaraka feodal 
lainnya; (d) struktur politik yang memunculkan sistem "kelembutan perempuan" (sifat feminine) tidak pernah mendapat kesempatan untuk turut mengambil keputusan dalam bidang politik; (e) struktur sosial religius, memunculkan pandangan "perempuan yang kehidupan religiusnya bermutu" adalah mereka yang menafsirkan kitab suci sebagai sabda Tuhan, tanpa mempersoalkan budaya patriarkhat yang melatarbelakangi penulisan kitab suci tersebut.

Selain kemiskinan kultural, yang menjadi penyebab terjadinya feminisasi kemiskinan yaitu kemiskinan struktural. Dalam kaitannya dengan hal tersebut, Charles (1968) sebagaimana yang dikutip oleh Susanto (2006) menyatakan bahwa orang miskin dapat dipandang sebagai bagian dari masyarakat yang tertekan oleh faktor-faktor eksternal. Ini artinya, dalam struktur masyarakat terdapat sekelompok orang yang melakukan tindakan eksploitasi terhadap kelompok masyarakat lainnya. Selanjutnya, masih menurut Charles, budaya kemiskinan tidak diwariskan secara turun temurun , tapi justru budaya itu muncul karena terdapatnya situasi yang menekan dari struktur dan sistem sosial dalam masyarakat luas yang berada di luar komunitas itu sendiri.

Kemiskinan struktural dapat diartikan sebagai kondisi kemiskinan yang dialami oleh suatu masyarakat yang penyebab utamanya bersumber pada struktur sosial yang berlaku dalam masyarakat itu sendiri. Struktur sosial yang berlaku telah mengurung mereka dalam suasana kemiskinan secara turun-temurun selama bertahun-tahun. Kemiskinan struktural merupakan kemiskinan yang diderita oleh suatu golongan masyarakat karena struktur sosial masyarakat tidak dapat ikut menggunakan sumber-sumber pendapatan yang sebenarnya tersedia bagi mereka (Kasim, 2006).

Sesungguhnya, secara struktural pemerintah telah berusaha membuka ruang agar perempuan dapat mengakses sumber daya yang ada semaksimal mungkin. Misalnya UndangUndang telah mengamanahkan bahwa keterwakilan perempuan pada lembaga-lembaga politik formal sekurang-kurangnya $30 \%$. Namun pada kenyataannya, tidak semudah itu untuk direalisasikan. Jadi, sekalipun sudah dilahirkan berbagai landasan hukum untuk menghilangkan feminisasi kemiskinan di Indonesia, masih saja persoalan tersebut belum dapat teratasi.

\section{Pembebasan Jerat Feminisasi Kemiskinan}

Upaya pembebasan jerat feminisasi kemiskinan dapat dilakukan dengan menilik penyebab-penyebab terjadinya feminisme kemiskinan. Seperti yang sudah dikemukakan sebelumnya bahwa hal tersebut disebabkan oleh kemiskinan kultural dan kemiskinan struktural, sehingga upaya yang dapat ditempuh dalam upaya memutuskan mata rantai feminisasi kemiskinan yaitu: secara kultural melakukan perubahan nilai-nilai yang ada di masyarakat dan secara struktural melakukan perubahan struktural dengan memberikan pendidikan dan membuka pasar kerja yang nondiskriminatif.

Penduduk miskin cederung bersikap menerima dan menganggap kemiskinan sebagai nasib serta sikap neglect atau masa bodoh, pasrah, dan tidak ada gairah untuk mengubah nasib mereka. Dilahirkan dalam kemiskinan merupakan takdir seseorang. Mereka menganggap bahwa sebelum roh ditiupkan, telah ditentukan tiga hal dan termasuk di dalamnya adalah harta, sehingga jika saat ini mereka berada dalam kemiskinan, itu memang sudah kehendakNya.

Oleh karena itu, jalan pertama yang harus ditempuh dalam upaya pembebasan jerat feminisasi kemiskinan yaitu mengubah nilai-nilai sosial yang diberlakukan untuk perempuan oleh masyarakat, karena tidak mungkin mengubah struktur sosial tanpa mengubah mental masyarakat terlebih dahulu. Mental yang terwujud dalam nilai-nilai sosial yang tidak membebaskan perempuan untuk menikmati fasilitas-fasilitas dan sumber daya yang ada, seperti pendidikan. Sejalan dengan yang dinyatakan oleh International Labour Office (2004), menyatakan bahwa dalam upaya pembebasan jerat feminisasi kemiskinan di Indonesia, tidak 
cukup dengan hanya menyediakan sumber daya ekonomi bagi perempuan. Namun, perlu adanya kesetaraan gender dalam masyarakat agar perempuan dapat memiliki kesempatan untuk menggunakan fasilitas-fasilitas dan sumber daya yang ada secara efisien.

Untuk mewujudkan hal tersebut, maka perlu melakukan sosialisasi tentang keadilan dan kesetaraan gender di seluruh kalangan masyarakat, sehingga dapat mengubah mental masyarakat termasuk orang-orang miskin. Sedangkan menurut Oscar Lewis (1966) sebagaimana yang dikutip oleh Mutaqien (2006), "untuk menghilangkan budaya kemiskinan tersebut menyarankan agar orang-orang miskin bersatu dalam suatu organisai."

Setelah mengubah nilai-nilai yang ada di masyarakat menjadi nilai-nilai yang membukakan pintu sebesar-besarnya bagi perempuan dalam mengakses fasilitas-fasilitas dan sumber daya yang ada, selanjutnya melakukan perubahan secara struktural karena selama ini program yang dilakukan pemerintah dalam menaggulangi kemiskinan hanya upaya dari pembebasan atas kemiskinan material an sich. Padahal, kemiskinan bukan hanya dari segi material saja. Langkah yang terlihat dari pemerintah hanyalah pembagian kredit kepada petani kecil, Pendidikan Kesejahteraan Keluarga (PKK), Posyandu, pembangunan sarana sanitasi, Inpres Desa Tertinggal (IDT), pembangunan infrastruktur, penyuluhan pertanian, dan lainlain. Namun, aspek yang belum disentuh pemerintah adalah keadilan. Di satu sisi pemerintah berusaha mengentaskan kemiskinan, namun di sisi lain masyarakat miskin melihat adanya ketidakadilan. Masyarakat kelas kaya mendapatkan berbagai kemudahan dan masyarakat miskin semakin kesulitan (Mutaqien, 2006).

Oleh karena itu, Mutaqien (2006) menyatakan bahwa ada tiga faktor penting yang harus dipenuhi pemerintah untuk dapat mengentaskan kemiskinan, yaitu: (a) memiliki komitmen konkret (good will) untuk benar-benar mengentaskan kemiskinan, (b) alokasi dana yang memadai, (c) strategi dan paradigma yang digunakan oleh pemerintah. Selain itu, memperbaiki dunia pendidikan agar tidak diskriminatif dan pasar kerja menjadi lebih terbuka untuk perempuan merupakan beberapa solusi yang dapat ditempuh dalam menanggulangi kemiskinan. Karena lebih baik memfasilitasi kaum perempuan untuk mengakses fasilitasfasilitas dan sumber daya yang ada, daripada menyantuni. Persis perumpaan kuno yang dikutip oleh Coleridge (1997), "seseorang yang disedekahi sekeranjang ikan bakal kenyang selama satu-dua hari; jika dia mendapat kail maka kenyanglah dia seumur hidupnya-malah bisa juga jadi pengekspor cakalang."

Pendidikan yang nondiskriminatif merupakan salah satu upaya yang dapat dilakukan untuk melepas jerat feminisasi kemiskinan. Pendidikan merupakan salah satu strategi untuk meningkatkan sumber daya manusia, khususnya kualitas nonfisik. Kualitas nonfisik direfleksikan oleh tingkat pengetahuan dan keterampilan yang dimiliki seseorang (Lains, 1987; Kasim, 2006; Zahrawati, 2018). Peningkatan kualitas sumber daya manusia melalui pendidikan mempunyai kaitan erat dengat taraf hidup manusia (Simanjuntak, 1992; Kasim, 2006). Peran pendidikan dalam memerangi kemiskinan sangat menentukan. Negara yang berhasil memerangi kemiskinan adalah mereka yang mampu memberikan pendidikan kepada seluruh warga bangsanya. Lebih dari itu, keberhasilan negara menyediakan pendidikan bagi warga bangsanya merupakan kunci sukses negara tersebut mencapai kemakmuran dan kesejahteraan (Zamroni, 2010).

Selain pendidikan yang nondiskriminatif, upaya yang dapat dilakukan dalam memberantas feminisasi kemiskinan yaitu: perlu upaya penyediaan seutuhnya pekerjaan yang produktif dan layak, terutama untuk perempuan dan kaum muda. Terkait kesetaraan gender dan pemberdayaan perempuan, perlu kerja keras untuk meningkatkan kontibusi perempuan dalam pekerjaan upahan (Mahmud, 2015). Berhubungan dengan hal tersrbut, Purwanto (2007) menyatakan bahwa Usaha Kecil dan Menengah (UKM) memiliki potensi yang besar untuk dapat membantu pemerintah mengentaskan kemiskinan, dengan memberikan kesempatan kerja kepada penduduk yang tidak tertampung di sektor formal atau sektor usaha besar, 
penciptaan Produk Domestik Bruto, dan mendorong ekspor. Pemerintah sebagai pembuat kebijakan, seyogyanya memberi perhatian yang lebih adil kepada Usaha Kecil Menengah dengan membuat kebijakan-kebijakan yang mampu memberdayakan Usaha Kecil Menengah, sehingga ke depan Usaha Kecil Menengah akan dapat dijadikan sebagai andalan untuk penyerapan tenaga kerja dan pengentasan kemiskinan.

\section{Kesimpulan}

Berbagai faktor yang menjadi penyebab terjadinya kemiskinan telah dikemukakan oleh berbagai ahli. Namun berkaitan dengan feminisasi kemiskinan, yang menjadi faktor utama yaitu kemiskinan kultural dan kemiskinan struktural. Menilik nilai-nilai yang diberlakukan untuk perempuan dalam masyarakat berupa pernikahan di usia muda, keharusan segera memiliki anak, kehamilan berkali-kali untuk memperoleh anak laki-laki, dan jam kerja yang panjang di rumah dapat membatasi akses perempuan terhadap fasilitas-fasilitas dan sumber daya yang ada. Selain itu, secara struktural perempuan juga mengalami kesulitan dalam memperoleh pendidikan dan pekerjaan yang non diskriminatif. Hal ini tidak lepas dari pengaruh nilai-nilai yang diberlakukan untuk perempuan oleh masyarakat. Oleh karena itu, dibutuhkan upaya pembebasan dari feminisasi kemiskinan yang diawali dengan mengubah nilai-nilai yang ada di masyarakat dan memperbaiki struktur agar perempuan juga dapat mengakses fasilitas-fasilitas yang ada dan menikmati kehidupan yang layak. Karena sekalipun sudah dilahirkan berbagai landasan hukum untuk menghilangkan feminisasi kemiskinan di Indonesia, masih saja persoalan tersebut belum dapat teratasi, disebabkan oleh masih adanya nilai-nilai sosial yang membatasi perempuan dalam mengakses fasilitas-fasilitas dan sumber daya yang ada.

\section{Referensi}

Coleridge, P. (1997). Pembebasan dan Pembangunan; Perjuangan Penyandang Cacat di Negara-negara Berkembang. (Terjemahan Omi Intan Naomi). United Kingdom: Oxfam.

Haughton, J. \& Khandker, S.R. (2012). Pedoman tentang Kemiskinan dan Ketimpangan; Handbook on Poverty \& Inequality. (Diterjemahkan oleh Tim Penerjemah World Bank). Washington, DC: The International Bank for Reconstruction and Development

Henslin, J.M. (2006). Sosiologi Jilid I dengan Pendekatan Membumi. (Diterjemahkan oleh Kamanto Sunarto). New Jersey: Pearson Education Inc.

International Labour Office. (2004). Jender dan Kemiskinan. Jakarta: Kantor Perburuhan Internasional.

Irianto, S. (2003). Perempuan di antara Berbagai Pilihan Hukum. Jakarta: Yayasan Obor Indonesia.

Kasim, M. (2006). Karakteristik Kemiskinan; Strategi Penanggulangannya. Jakarta: Indomedia Global.

Listyaningsih, U. (2004). Dinamika Kemiskinan di Yogyakarta. Yogyakarta: Universitas Gadjah Mada Press \& PEG-USAID.

Mahmud, M. A. (2015). Gender dan Kehutanan Masyarakat. Yogyakarta: Deepublish.

Murniati, A. N. P. (2004). Getar Gender; Perempuan Indonesia dalam Perspektif Agama, Budaya, dan Keluarga. Buku Kedua. Yogyakarta: Yayasan Indonesia Tera.

Mutaqien, A. (2006). Menuju Indonesia Sejahtera; Upaya Pengentasan Kemiskinan. Jakarta: Khanata-Pustaka LP3ES Indonesia. 
Purwanto, E. A. (2007). Mengkaji Potensi Usaha Kecil dan Menengah (UKM) untuk Pembuatan Kebijakan Anti Kemiskinan di Indonesia. Jurnal Ilmu Sosial dan Ilmu Politik, 10(3), 295-324.

Republik Indonesia. (1945). Undang-Undang Dasar Negara Republik Indonesia Tahun 1945.

Santi, S. (2007). Perempuan dan Kemiskinan; Pembangunan, Kebijakan, dan Feminisasi Kemiskinan. Forum Ilmiah Indonesia, 4(1), 1-14.

Santrock, J.W. (2003). Adolescene; Perkembangan Remaja Edisi Keenam. (Diterjemahkan oleh Shinto B. Adelar \& Sherly Saragih). Burr Ridge, United State: Times Mirror Higher Education.

Schaefer, R.T. (2012). Sosiologi Edisi 12 Buku 1. (Diterjemahkan oleh Anton Novenanto \& Diah Tantri Dwiandiani). New York: McGraw Hill.

Siahaan, N.H.T. (2004). Hukum Lingkungan dan Ekologi Pembangunan. Jakarta: Erlangga.

Sumodiningrat, G. \& Nugroho, R. (2005). Membangun Indonesia Emas; Model Pembangunan Indonesia Baru Menuju Negara-bangsa yang Unggul dalam Persaingan Global. Jakarta: PT. Elex Media Komputindo.

Susanto, H. (2006). Dinamika Penanggulangan Kemiskinan; Tinjauan Historis Era Orde Baru. Jakarta: Khanata Pustaka LP3ES Indonesia.

Sustainable Development Goals.http://www.un.org/sustainabledevelopment/sustainabledevelopment-goals/. (diakses pada tanggal 26 Maret 2020).

Trijono, L. (2007). Pembangunan sebagai Perdamaian. Jakarta: Yayasan Obor Indonesia.

Zahrawati, F. (2018). Membebaskan Anak Tuna Daksa dalam Mewujudkan Masyarakat Multikultural Demokratis. Jurnal Al-Maiyyah, 11(1), 171-187.

Zamroni. (2010). Pendidikan dan Kemiskinan. Dalam Tukiran, Agus Joko Piyoto, \& Pande Made Kutanegara (Eds). Akses Penduduk Miskin terhadap Kebutuhan Dasar. Yogyakarta: Pusat Studi Kependudukan dan Kebijakan Universitas Gadjah Mada. 